THE HUMOR OF KIERKEGAARD 



\title{
THE HUMOR OF
}

\section{KIERKEGAARD}

\author{
A N A N THOLOGY
}

\section{Søren Kierkegaard}

Edited and Introduced by

Thomas C. Oden 
Copyright () 2004 by Princeton University Press

Published by Princeton University Press, 41 William Street, Princeton, New Jersey 08540

In the United Kingdom: Princeton University Press, 3 Market Place, Woodstock, Oxfordshire OX20 1SY

All Rights Reserved

Library of Congress Cataloging-in-Publication Data

Kierkegaard, Søren, 1813-1855.

[Selections. English. 2004]

The humor of Kierkegaard : an anthology / Søren Kierkegaard ; edited and introduced by Thomas C. Oden.

p. $\mathrm{cm}$.

Includes bibliographical references and index.

ISBN 0-691-07406-2 (alk. paper) - ISBN 0-691-02085-X (pbk. : alk. paper)

1. Wit and humor. 2. Kierkegaard, Søren, 1813-1855-Humor. I. Oden Thomas C. II. Title.

\section{B4372.E5 2004}

$198^{\prime} .9-\mathrm{dc} 22 \quad 2003064125$

British Library Cataloging-in-Publication Data is available

This book has been composed in Goudy Old Style Typeface

Printed on acid-free paper. $\infty$

www.pupress.princeton.edu

Printed in the United States of America

$\begin{array}{llllllllll}10 & 9 & 8 & 7 & 6 & 5 & 4 & 3 & 2 & 1\end{array}$ 